Note

\section{An Enzyme in Sweet Potato Root which Catalyzes the Conversion of Chlorogenic Acid, 3-Caffeoylquinic Acid, to Isochlorogenic Acid, 3,5-Dicaffeoylquinic Acid}

\author{
Mineo KoJIma and Tadao Kondo* \\ Institute for Biochemical Regulation, \\ Faculty of Agriculture and \\ *Chemical Instrument Center, Nagoya University, \\ Chikusa-ku, Nagoya 464, Japan
}

Received January 16, 1985

When sweet potato root tissue is sliced and incubated, much synthesis of chlorogenic acid (3-caffeoylquinic acid) and isochlorogenic acid (isomers of dicaffeoylquinic acid) takes place. ${ }^{1 \sim 4)}$ Our earlier tracer experiment ${ }^{4)}$ suggested that chlorogenic acid was directly converted to isochlorogenic acid through a one-step reaction in injured sweet potato root.

This communication deals with the detection of the enzyme activity in sweet potato root which catalyzes the conversion of chlorogenic acid to isochlorogenic acid $(3,5-$ dicaffeoylquinic acid).

Acetone powder was prepared from sweet potato (Ipomoea batatas Lam, cv, Norin 1) root slices, $0.5 \mathrm{~cm}$ thick, which had been incubated at $25^{\circ} \mathrm{C}$ for $48 \mathrm{hr}$. The powder $(3 \mathrm{~g})$ was extracted with $30 \mathrm{ml}$ of $0.1 \mathrm{M}$ phosphate buffer, pH 7.0 , containing $0.1 \%$ mercaptoethanol. The extract was brought to $70 \%$ saturation with ammonium sulfate and the resultant precipitate was collected by centrifugation at $3.2 \times 10^{4} \mathrm{~g}$ for $15 \mathrm{~min}$. The precipitate

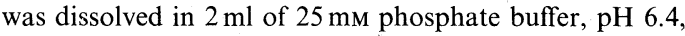
and put on a column of Sephadex G-25 $(2 \times 24 \mathrm{~cm})$ preequilibrated with the same buffer. The void volume fraction from the column was assayed for its activity in the conversion of chlorogenic acid to isochlorogenic acid by the following procedures.

A reaction mixture consisted of $6 \mu \mathrm{mol}$ of chlorogenic acid, $8 \mu \mathrm{mol}$ of magnesium chloride, $7.5 \mu \mathrm{mol}$ of phosphate (pH 6.4) and a certain amount of enzyme in a final volume of $540 \mu \mathrm{l}$. The mixture was incubated at $30^{\circ} \mathrm{C}$ for a certain period under nitrogen gas to inhibit the oxidation by contaminating polyphenoloxidase. The reaction was terminated by the additions of $3 \mathrm{ml}$ of ethanol and $2 \mathrm{ml}$ of acetone. The mixture was left at room temperature for $30 \mathrm{~min}$ and centrifuged at $2 \times 10^{3} \mathrm{~g}$ for $10 \mathrm{~min}$. The supernatant was condensed under reduced pressure at $30^{\circ} \mathrm{C}$, put onto a column of Develosil ODS $5(4 \mathrm{~mm} \times 25 \mathrm{~cm})$ and eluted with $25 \%$ acetonitrile containing $1 \%$ acetic acid at a flow rate of $0.5 \mathrm{ml} / \mathrm{min}$. The amount of the enzyme reaction product (3,5-dicaffeoylquinic acid) was determined from the area of the peak at $9 \mathrm{ml}$ of elution volume.

The enzyme reaction was done on a large scale to prepare the reaction product for identification. The reaction mixtue after termination by additions of ethanol and acetone was chromatographed on paper (Whatman 3 MM) using 5\% acetic acid (AW). The fluorescent band at $R f 0.23$ was cut off and eluted with a mixture of ethanol and water $(1: 1, \mathrm{v} / \mathrm{v})$. The eluate was condensed with a rotary evaporator and used for the liquid chromatography described above. The main peak fractions at $9 \mathrm{ml}$ of elution volume were pooled and used for identification.

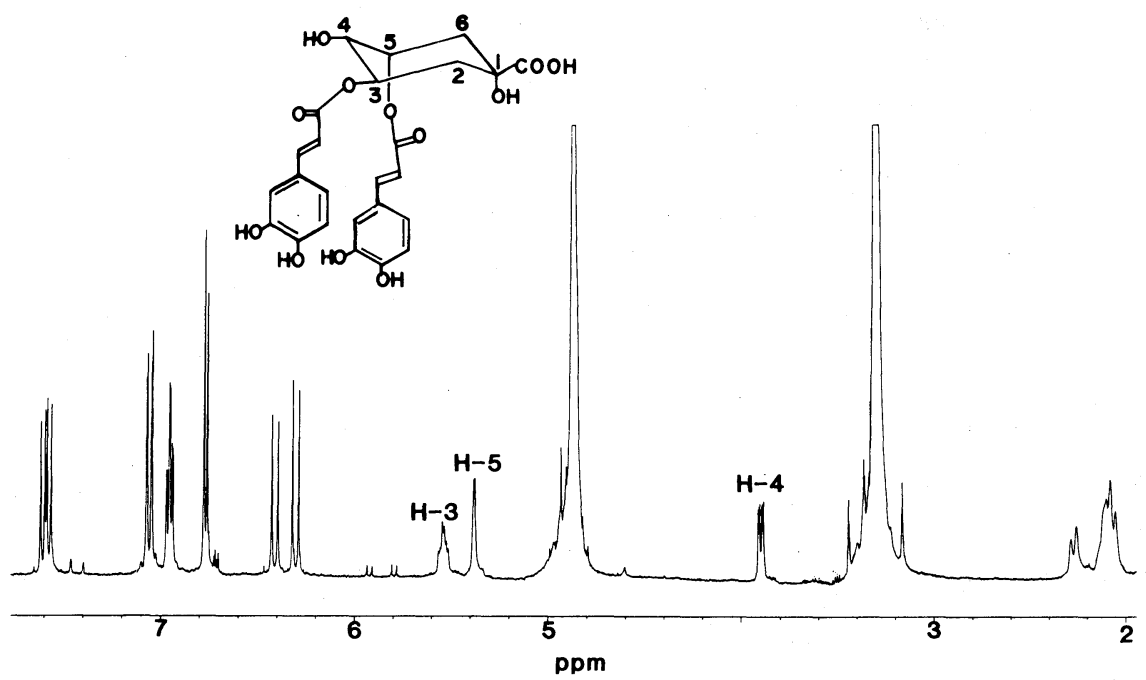

FIG. 1. ${ }^{1} \mathrm{H}-\mathrm{NMR}$ Spectrum of Enzyme Reaction Product $\left(500 \mathrm{MHz}\right.$, in $\left.\mathrm{CD}_{3} \mathrm{OD}\right)$. 


\section{Table I. Molar Ratio of Enzyme Reaction Products}

A reaction mixture consisting of $7.6 \mu \mathrm{mol}$ of chlorogenic acid, $10 \mu \mathrm{mol}$ of magnesium chloride, $9.4 \mu \mathrm{mol}$ of phosphate $(\mathrm{pH} 6.4)$ and $820 \mu \mathrm{g}$ protein of enzyme in a final volume of $680 \mu \mathrm{l}$ was incubated at $30^{\circ} \mathrm{C}$ for $30 \mathrm{~min}$. The reaction was terminated and used for liquid chromatography to isolate 3,5-dicaffeoylquinic acid, caffeic acid, and quinic acid, as described in text. The peak fraction of each product was collected and assayed. 3,5-Dicaffeoylquinic acid and caffeic acid were measured by the optical density at $326 \mu \mathrm{m}$ and the quinic acid was measured by the PT reaction. It was assumed that caffeic acid was produced by hydrolysis of the substrate, chlorogenic acid.

\begin{tabular}{|c|c|c|c|}
\hline & \multicolumn{3}{|c|}{ Amount of enzyme reaction products (nmol) } \\
\hline & $\begin{array}{l}\text { 3,5-Dicaffeoylquinic } \\
\text { acid }\end{array}$ & $\begin{array}{l}\text { Quinic } \\
\text { acid }\end{array}$ & $\begin{array}{l}\text { Caffeic } \\
\text { acid }\end{array}$ \\
\hline $\begin{array}{l}\text { Gross amount in the reaction mixture } \\
\text { after incubation }\end{array}$ & 18.0 & 25.0 & 5.9 \\
\hline $\begin{array}{l}\text { Amount of quinic acid produced con- } \\
\text { comitantly with caffeic acid production }\end{array}$ & - & 5.9 & - \\
\hline $\begin{array}{l}\text { Net amount of quinic acid due to the } \\
\text { enzyme reaction producing } 3,5- \\
\text { dicaffeoylquinic acid }\end{array}$ & - & 19.1 & - \\
\hline $\begin{array}{l}\text { Molar ratio of } 3,5 \text {-dicaffeoylquinic } \\
\text { acid and quinic acid } \\
\text { produced by the enzyme reaction }\end{array}$ & $\begin{array}{c}1 \\
(18.0)\end{array}$ & $\begin{array}{c}1.1 \\
(19.1)\end{array}$ & - \\
\hline
\end{tabular}

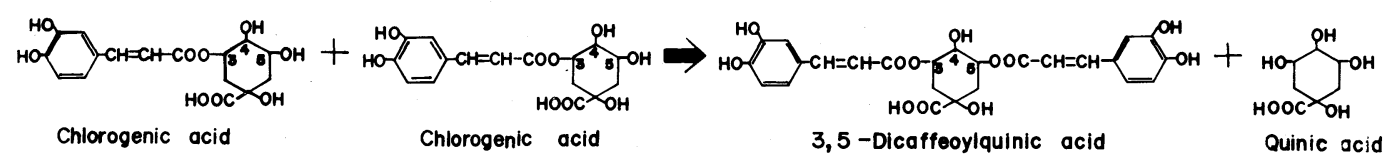

FIG. 2. Proposed Enzymatic Reaction for Production of 3,5-Dicaffeoylquinic Acid.

The reaction product showed the same UV-absorption spectrum as chlorogenic acid; UV $\lambda_{\max }^{\mathrm{EtOH}} \mathrm{nm}: 245,326$. The reaction product and authentic chlorogenic acid (Aldrich Chemical Co.) were hydrolyzed in $0.5 \mathrm{~N} \mathrm{NaOH}$ at $30^{\circ} \mathrm{C}$ under nitrogen gas for $75 \mathrm{~min}$. The hydrolyzates were neutralized by $\mathrm{HCl}$ and chromatographed on paper using three solvent systems; AW, n-butanol-acetic acid-water, $4: 1: 2, \quad \mathrm{v} / \mathrm{v} \quad(\mathrm{BAW})$ and $n$-butanol-pyridine-water, $14: 3: 3, \mathrm{v} / \mathrm{v}$ (BPW). The chromatographed papers were examined first by a UV lamp to detect the aromatic moiety and then cut into $1-\mathrm{cm}$ pieces, on which color was developed $^{5)}$ with periodic. acid and 2-thiobarbituric acid (PT reaction) which is positive with quinic acid and deoxysugar, to detect the non-aromatic moiety. The hydrolyzate of the enzyme reaction product showed the same two spots as those of chlorogenic acid on every chromatogram. The $R f$ value of the fluorescent spot coincided with that of authentic caffeic acid and that of the pink spot by PT reaction with that of authentic D-quinic acid. The $R f$ values of spots of the aromatic and non-aromatic moieties of the product and chlorogenic acid on chromatograms developed by various solvent systems were as follows: 0.33, 0.95 (AW); 0.85, 0.30 (BAW); and 0.51, 0.02 (BPW), respectively.

The structure of the reaction product was 3,5-dicaffeoyl- quinic acid ${ }^{6,7}$ from the following evidence of the spectrum of ${ }^{1} \mathrm{H}-\mathrm{NMR}$ (Fig. 1). First, the spectrum indicated that it consisted of one molecular quinic and two molecular caffeic acids. Second, the hydroxyl groups at the 3 and 5 positions of quinic acid must be acylated with caffeic acid since the signals at 5.38 and $5.53 \mathrm{ppm}$ which were assigned to $\mathrm{H}-3$ and $\mathrm{H}-5$, respectively, by spin-spin decoupling analysis $\left(J_{2 \mathrm{e}, 3}=5 \mathrm{~Hz}, \quad J_{2 \mathrm{a}, 3}=J_{3,4}=10 \mathrm{~Hz}, \quad J_{4,5}=J_{5,6 \mathrm{a}}=\right.$ $J_{5,6 \mathrm{e}}=3 \mathrm{~Hz}$ ) appeared more than $1.0 \mathrm{ppm}$ lower in the field than those of quinic acid.

The enzyme reaction mixture contained only chlorogenic acid, 3-caffeoylquinic acid, as a substrate. As mentioned above, the enzyme produced 3,5-dicaffeoylquinic acid as one of the reaction products. Consequently, it was expected that one molecule of quinic acid was produced concomitantly with production of one molecule of 3,5-dicaffeoylquinic acid, and it was (Table I).

The amount of 3,5-dicaffeoylquinic acid produced by the enzyme reaction increased with incubation time and enzyme concentration (data not shown). On the other hand, no 3,5-dicaffeoylquinic acid was detected with any of the following reaction mixtures; the complete reaction mixture containing active enzyme of which reaction was terminated at zero time incubation, the complete reaction mixture which was incubated with boiled enzyme, or the 
reaction mixture without chlorogenic acid which was incubated with active enzyme.

The results in this communication indicated the occurrence of an enzyme in sweet potato root which catalyzes the reaction shown in Fig. 2. It is noteworthy that the enzyme produced only one isomer, 3,5-dicaffeoylquinic acid, among three possible isomers of dicaffeoylquinic acid. $^{6 \sim 9)}$

Acknowledgment. The authors express their thanks to Dr. I. Uritani for his advice and encouragement throughout this work.

\section{REFERENCES}

1) I. Uritani and K. Muramatsu, Nippon Nôgeikagaku Kaishi, 27, 29 (1953).
2) I. Uritani, Nippon Nôgeikagaku Kaishi, 27, 165 (1953).

3) I. Uritani and M. Miyano, Nature, 175, 812 (1955).

4) M. Kojima and I. Uritani, Plant \& Cell Physiol., 13, 311 (1972).

5) T. Minamikawa and S. Yoshida, "Methods in Secondary Metabolism of Higher Plants" (in Japanese), Japan Scientific Societies Press, Tokyo, 1981, pp. $67 \sim 68$.

6) M. L. Scarpati and M. Guiso, Tetrahedron Lett., 2851 (1964).

7) B. N. Timmermann, J. J. Hoffmann, J. Natural Prod., 46, 365 (1983).

8) Y. Inoue, S. Aoyagi and K. Nakanishi, Chem. Pharm. Bull., 13, 100 (1965).

9) Z. Grodzinska-Zachwieja, W. Kahl and A. Warchol, J. Chromatogr., 29, 362 (1967). 